\title{
Deployment of a stand-alone hybrid renewable energy system in coastal areas as a sustainable energy source
}

\author{
A. Kasaeiana*, A. Razmjoob, R. Shirmohammadia, F. Pourfayaza, A. Sumperb,c \\ aDepartment of Renewable Energies, Faculty of New Sciences \& Technologies, University of Tehran, \\ Tehran, Iran. \\ b Escolla Técnica Superior d'Enginyeria Industrial de Barcelona (ETSEIB), Universitat Politécnica de \\ Catalunya (UPC), Av. Diagonal, 647, 08028 Barcelona, Spain. \\ cCentre d'Innovació, Tecnològica en Convertidors Estàtics i Accionaments (CITCEA-UPC), Escola \\ Tècnica Superior d'Enginyeria Industrial de Barcelona (ETSEIB), Universitat Politècnica de \\ Catalunya (UPC), Av. Diagonal, 647, Pl. 2, 08028 Barcelona, Spain
}

Corresponding Author: akasa@ut.ac.ir, Tel: +98 9121947510

\begin{abstract}
Since the non-renewable energy sources merely are not able to fulfill the demand for electricity increasing steadily; therefore, solar and wind can be considered as environmentally friendly and omnipresent renewable energy sources for generating electrical energy. In this study, the techno-economic evaluation for two hybrid renewable energy systems is carried out to achieve this target for Bandar Dayyer. In this regard, using the Homer software, the total amount of electricity production by these systems are equal to $470176 \mathrm{~kW}$, of which, $22409 \mathrm{~kW}$ is provided by and PV-Generic system and $447767 \mathrm{~kW}$ by PV-diesel-Generic system. According to the results of this analysis, it should be mentioned that this area has an appropriate potential of wind speed and solar radiation; which means that it can be suitable for investment on the renewable energy site for electrical production.
\end{abstract}

Keywords: Renewable energy system; HOMER software; Solar energy; Wind energy.

\section{Introduction}

Adequate provision of energy has always been a crucial issue and is deemed as one of the best measures for estimating the economic growth and development of a country. In recent decades, increasing $\mathrm{CO}_{2}$ emission into the atmosphere is considered as one of the main reasons for global warming with adverse environmental effects such as sea level rise, floods, droughts, etc. Reduction of fossil fuels consumption by energy efficiency, carbon capture, and storage, conversion of $\mathrm{CO}_{2}$ to different products, application of renewable energies and reforestation 
1 are effective mitigation options [1-3]. On the other hand, regarding the increasing population

2 of the world, the rate of energy consumption increased and it causes further use of fossil fuels

3 [4]. Concerning these realities, employing more sustainable energy sources such as renewable energy can be considered as an appropriate solution for overcoming these problems and achieving sustainable development [5-7]. Renewable energy sources are clean, free and have many environmental and economic advantages than other conventional energy sources [8-12]. Without doubt among clean energies, solar and wind energy are the best and well-known sources of energy and according to the released statistics has a growing influential impact on energy services [13]. Moreover, solar and wind energy has an appropriate potential for supplying a remarkable part of the required energy in the world. Also, the recent breakthroughs in solar and wind energy technology and its related fields, has increased the efficiency of different equipment used in this industry [14]. In recent years, many works in this regard have been carried out in different countries which some of them, can be mentioned. Jahangiri et al.[15] investigated renewable energy power plants in Afghanistan. In this research, the potential of solar and wind energy was investigated for this country. A study regarding a photovoltaic thermal system for electricity production and low-grade heat was carried out in Iran [16]. Sen and Bhattacharyya [17] proposed a hybrid technology using homer software for electricity production in India. They investigated wind turbines, small-scale hydropower systems, solar photovoltaic, and bio-diesel generators for supplying electrical energy for remote villages. Ma et al. [18] proposed a solution for energy saving in a remote Island in Hong Kong for supporting the microgrid hybrid solar-wind system. A mathematical pattern showed using renewable systems based on PHS technology (Pumped hydro storage) could supply energy for remote regions completely. Ntanos et al. [19] investigated the relationship between energy consumption deriving from renewable energy sources with countries growth (belong to 25 European countries) and their labor forces. Amrollahi et al. [20] analyzied and modeled a stand-alone micro-grid for remote . In this study, the ability of demand response programming about of component size optimization of a micro-grid investigated by them. In this study also wind and solar energy were considered as main resources in order to energy supply for these regions. Tao Ma et al. [21] examined the expansion of energy storage of hybrid battery for remote regions by renewable energy systems. They investigated theoretical analysis and numerical simulation using related software for these systems and in order to enhance the performance of the HESS systems, were presented an electric inductor. Aktas et al. [22] investigated smart energy management using renewable energy and based on an algorithm. In this study, moreover real various operation experiential and tests for HESS systems, effective 
strategies according to SEMA (Smart energy management algorithm) and in order to support of the HESS (Hybrid energy storage system) systems has been suggested. Bölük et al. [23] considered the renewable energies with an ARDL (Applying the autoregressive distributed lag) approach in Turkey. In this research, the growth of renewable energy in this country and the effect on the environment were investigated. Razmjoo et al. [24] examined energy sustainability indicators for urban areas. In this study, the most important indicators related to energy were considered for improving the urban energy situation. Goel et al. [25] examined renewable energy systems such as PV, PEV (Plug-in electric vehicle) and HRES (Hybrid renewable energy system). Different hybrid energy systems including in off-grid and in grid linked PV systems that has two or more energy resources in order to energy production for rural electrification has been investigated in this article. Jung et al. [26] presented optimal planning and design of hybrid renewable energy for microgrids systems. They showed that the use of these technical and economic analyses could be beneficial for microgrid applications. Razmjoo et al. [27] performed wind and solar energy potential assessment for Zanjan city in Iran. The main goal of this research was implementing a renewable energy power station in this area for supplying energy.

In this paper, wind speed and solar radiation potentials are considered in order to investigate the feasibility of implementing a renewable energy power station for Bandar Dayyer of Iran. Using Homer software, economic analysis and electrical energy production for Bandar Dayyer by renewable energy is investigated for the first time. Although, due to the humid subtropical climate in the coastal areas in comparison with dry zones, some amount of generated energy will be lost. However, using these hybrid energy systems can produce a remarkable amount of energy for this area that this measure has positive environmental effects and enhancing the possibility of more access to energy for inhabitants in the future.

\section{Energy sustainability importance}

Energy supply is not a usual challenge and is extremely involved with security and political issues. On the other hand, access to energy for all is essential [28]. In addition, energy is an important sustainable development issue and can have an effect on social, economic and the environment development of any country [29]. Thus, ensuring the access to affordable, reliable, sustainable and modern energy should be considered by governments for people. With regard to this reality that fossil fuels are not sustainable energy sources and hurt the environment, 
1 having a sustainable energy plan for supplying energy needs, without risk, is necessary for the

2 future [30]. A balanced energy plan is less vulnerable. Furthermore, achieving sustainable

3 development without sustainable energy development is meaningless. In this regard, a

4 sustainable energy plan, for the protection of the environment and prevention of probable issues

5 for the future, should be applied in the practical plan of any nation. Actually, the highest target

6 of energy sustainability, is energy security and energy balance for different countries. Energy

7 sustainability has many advantages such as creating energy opportunity, energy security,

8 energy affordability, and energy reliability [31].

Fig. 1 presents the energy sustainability based on the demand and supply by 2050 . As it is seen, year-by-year, the role of renewable energy will be increased as a reliable source of energy.

- World Total Energy Demand - Projections (Sustainable Scenario)

Fig. 2 shows the Iran's Wind Atlas. In this Atlas, the regions which are marked with brown red, including the northern cities and several cities in the Sistan-Baluchestan province in the south, have the most desirable wind data. There are also other points with very good wind potentials, which are scattered in the central regions of the country.

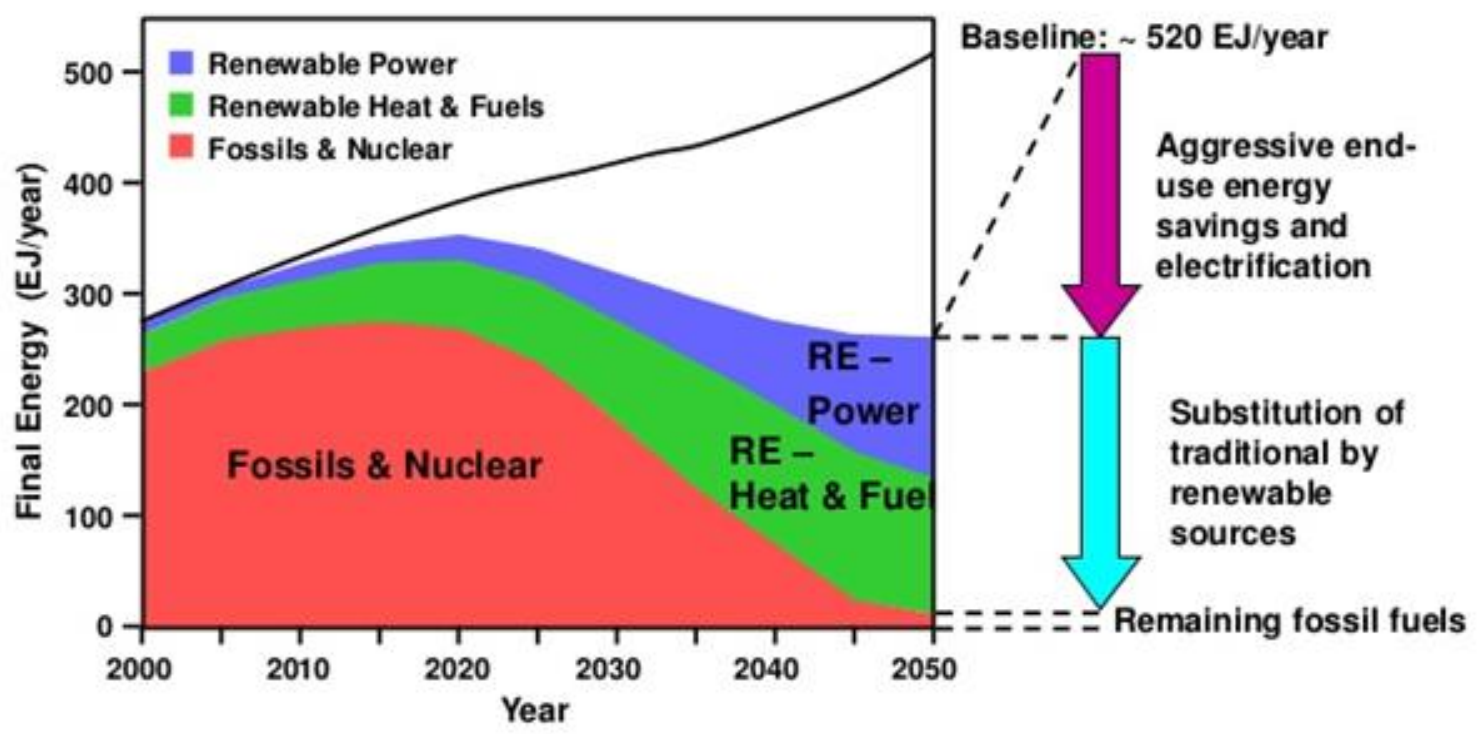

Fig. 1. Energy sustainability based on the demand and supply by 2050 [32] 


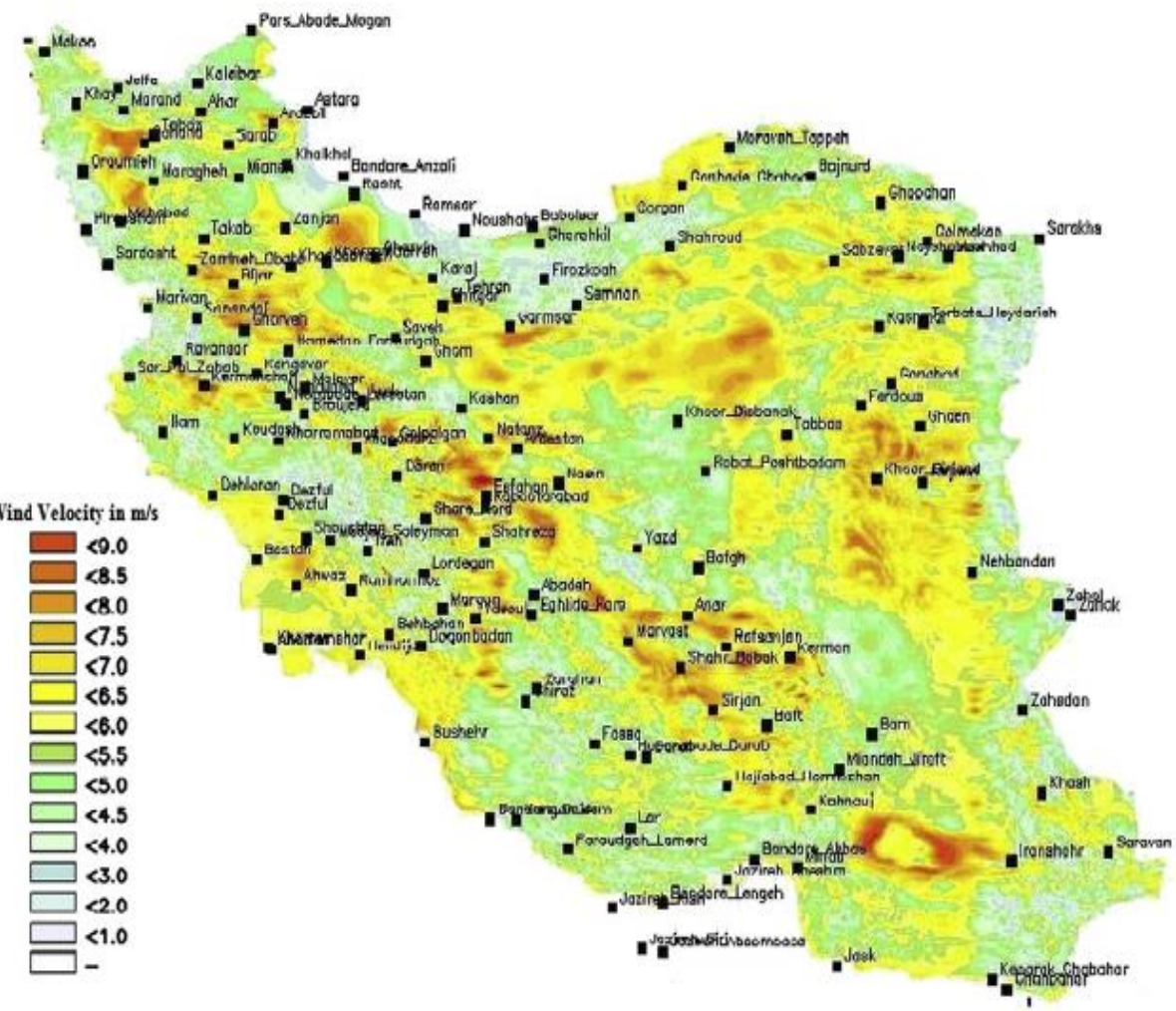

Fig 2. The Iran's Wind Atlas

4 The Iran's solar radiation atlas is shown in Fig. 3. In this Atlas, Iran is classified into a number 5 of regions based on their solar radiation potential. In this figure, the provinces which receive 6 the highest amount of radiation (Fars, Yazd, and Kerman), are within the middle black frame.

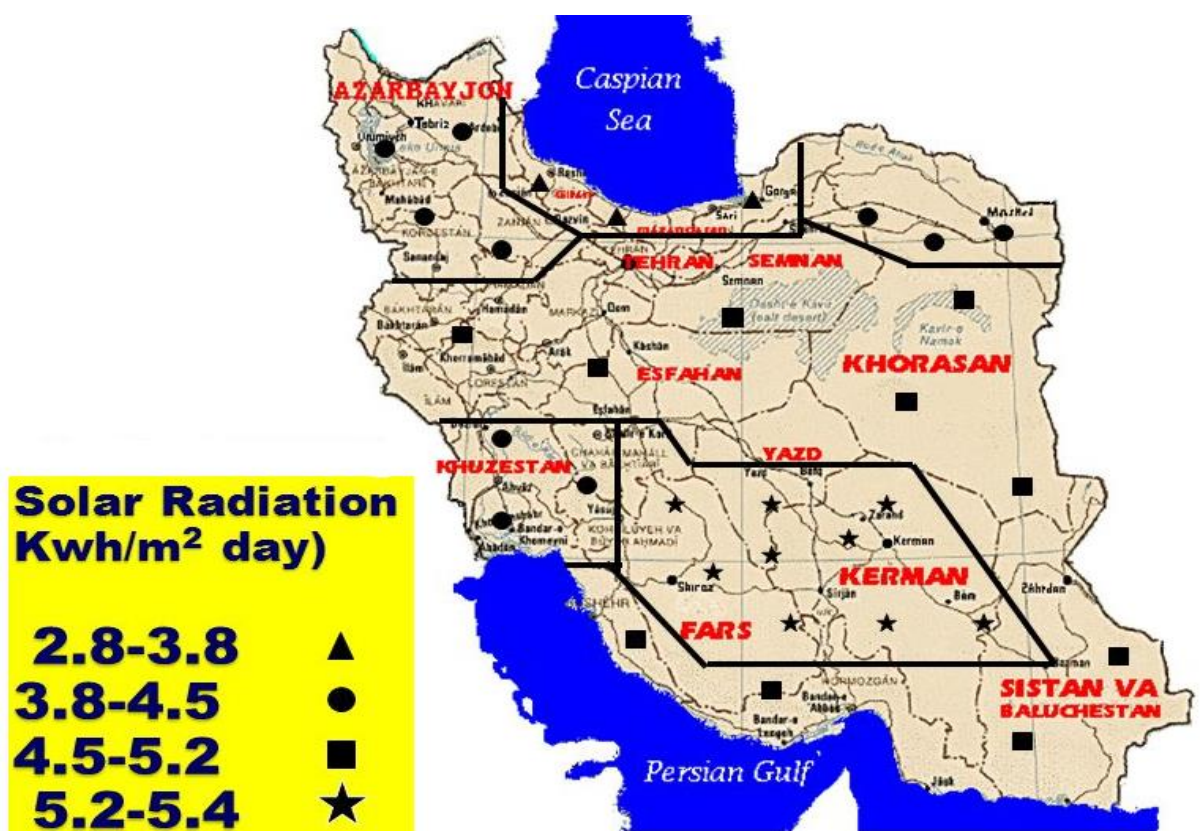


3 Site Location

4 Bandar Dayyer is a known port in the south of Iran, located in Bushehr province. This city is located at the coordinates of $27^{\circ} 50^{\prime} 24^{\prime \prime} \mathrm{N}$ and $51^{\circ} 56^{\prime} 16^{\prime \prime} \mathrm{E}$ and an altitude of 12 meters above sea level. At the 2011 census, its population was 24,083. In the south, winters are mild and the summers are very hot, having average daily temperatures in July exceeding $100.4^{\circ} \mathrm{F}$. Summer heat in areas abutting the Persian Gulf is accompanied by high humidity [33]. There are three cities near Bandar Dayyer as Kangan, Asaluyeh, and Jam. The distance from Dayyer to the center of Bushehr province is almost 180 kilometers. Fig. 4 shows the studied area on the Iran map in this research.

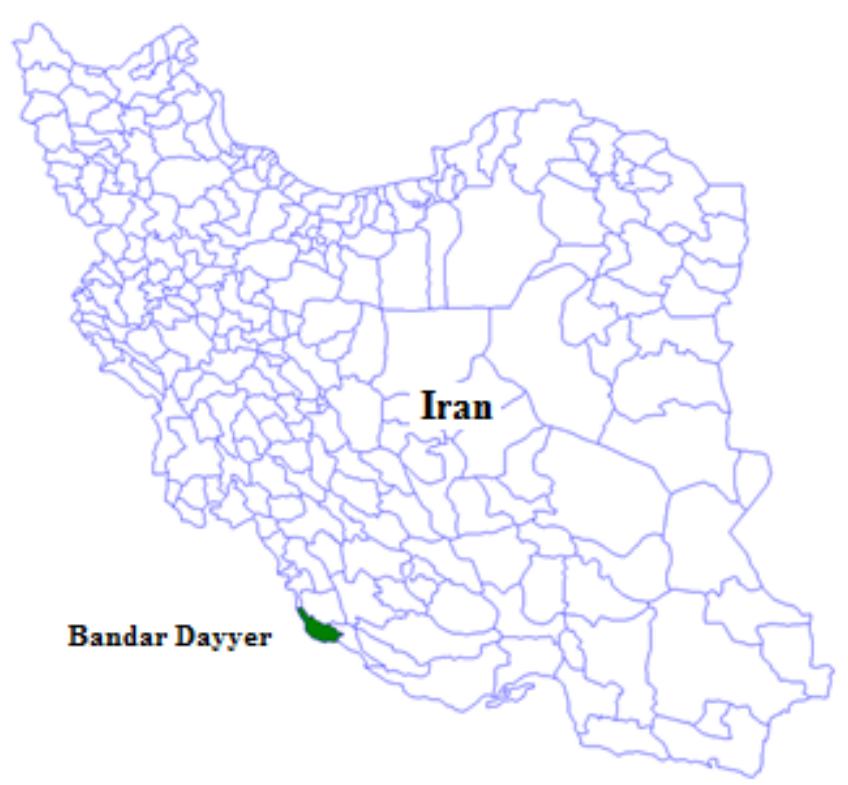

Fig 4. The studied area on the Iran map

15 
Table1. The average wind speed and daily radiation

\begin{tabular}{crc}
\hline Month & Wind speed $(\mathrm{m} / \mathrm{s})$ & Daily radiation $(\mathrm{kWh} / \mathrm{m} 2 . \mathrm{d})$ \\
\hline Jan & 3.778 & 3.72 \\
Feb & 3.711 & 4.73 \\
Mar & 3.902 & 5.44 \\
Apr & 2.987 & 6.77 \\
May & 3.7 & 7.61 \\
Jun & 3.413 & 7.95 \\
July & 2.718 & 7.85 \\
Aug & 2.343 & 7.34 \\
Sep & 2.493 & 6.7 \\
Oct & 2.542 & 5.77 \\
Nov & 3.098 & 4.31 \\
Dec & 3.403 & 3.42 \\
\hline
\end{tabular}

3 According to Table 1, Fig. 5 shows the average wind speed and daily radiation for Bandar 4 Dayyer.

5

6

7

8

9 Table 2 shows the specification of the wind turbine. This wind turbine has $10 \mathrm{~kW}$ rated power 10 with $15 \mathrm{~kW}$ maximum power. The detail of the turbine is specified in Table 2. 
Table 2. Specifications of the wind turbine with $10 \mathrm{~kW}$ rated power

\begin{tabular}{cc}
\hline Parameter & Value \\
\hline Rated Rotated speed & $200 \mathrm{r} / \mathrm{min}$ \\
\hline Blade diameter & $8.0 \mathrm{~m}$ \\
\hline Weight of the tower top & $600 \mathrm{~kg}$ \\
\hline Rated speed & $10 \mathrm{~m} / \mathrm{s}$ \\
\hline Rated power & $10 \mathrm{~kW}$ \\
\hline Max power & $15 \mathrm{~kW}$ \\
\hline Startup wind speed & $3 \mathrm{~m} / \mathrm{s}$ \\
\hline Work speed & $3-30 \mathrm{~m} / \mathrm{s}$ \\
\hline Security wind speed & $50 \mathrm{~m} / \mathrm{s}$ \\
\hline High of tower & $12 \mathrm{~m}$ \\
\hline Weight of the tower top & $60 \mathrm{~kg}$ \\
\hline Tower Steel tube model & $\varphi 219 \mathrm{~mm}$ \\
\hline Capacity and quantity of battery & $12 \mathrm{~V} 200 \mathrm{AH} 18 \mathrm{pcs}$ \\
\hline Design lifetime & 20 years
\end{tabular}

Table 3 shows the specification of the diesel generator with $100 \mathrm{~kW}$. This diesel generator has

$4100 \mathrm{~kW}$ capacity with the rated voltage of $400 / 230 \mathrm{~V}$. The detail of the diesel generator is 5 specified in Table 3.

Table 3. Specification of the diesel generator with $100 \mathrm{~kW}$ capacity

\begin{tabular}{cc}
\hline Parameter & Value \\
\hline Rated Power & $5 \mathrm{~kW} 3500 \mathrm{~kW}$ \\
\hline Rated Voltage & $400 / 230 \mathrm{~V}$ \\
\hline Speed & $1500 \mathrm{r} / \mathrm{min}$ \\
\hline Option & Automatic Transfer Switch \\
\hline Generator Type & Open, Silent, Trailer, ATS \\
\hline Alternator & AC phase \\
\hline Transport Package & Wooden, Pallet or Customized \\
\hline Rated current & $20 \mathrm{~A}-7000 \mathrm{~A}$ \\
\hline Prime power & $125 \mathrm{~kW}$ \\
\hline Standby power & $137.5 \mathrm{~kW}$ \\
\hline Frequency & $50 \mathrm{HZ} / 60 \mathrm{HZ}$ \\
\hline Voltage & $400 \mathrm{~V} / 230 \mathrm{~V}$ \\
\hline Fuel consumption at $100 \%$ load & $238 \mathrm{~g} / \mathrm{kWh}$ \\
\hline
\end{tabular}


1

2 Table 4 shows the specification of the Generic flat plate PV. The capacity of this Generic flat 3 plate is $10 \mathrm{~kW}$ with the work time of $24 \mathrm{HRS} / \mathrm{DAY}$. The detail of this solar panel is specified 4 in Table 4.

Table 4. Specification of the flat plate PV with $10 \mathrm{~kW}$ capacity

\begin{tabular}{cc}
\hline Parameter & Value \\
\hline Rated Capacity & $10 \mathrm{~kW}$ \\
\hline Work Time (h) & 24 HRS/DAY \\
\hline Battery Type & Lithium \\
\hline Output Frequency & $50 / 60 \mathrm{hz}$ \\
\hline Specification & Normal \\
\hline System type & On-Off-Grid Solar System \\
\hline Est. Time (Days) & PWM or MPPT \\
\hline Controller Type & Home, Factory, Commercial \\
\hline USING & free maintenance Gel battery \\
\hline Battery & $380 \mathrm{~V}, 220 \mathrm{~V}, 110 \mathrm{~V}$
\end{tabular}

6

7 Also, Fig. 6 shows the real meteorological station of Bandar Dayyer. As it can be seen in this 8 figure, the meteorological equipment belongs to the studied area.

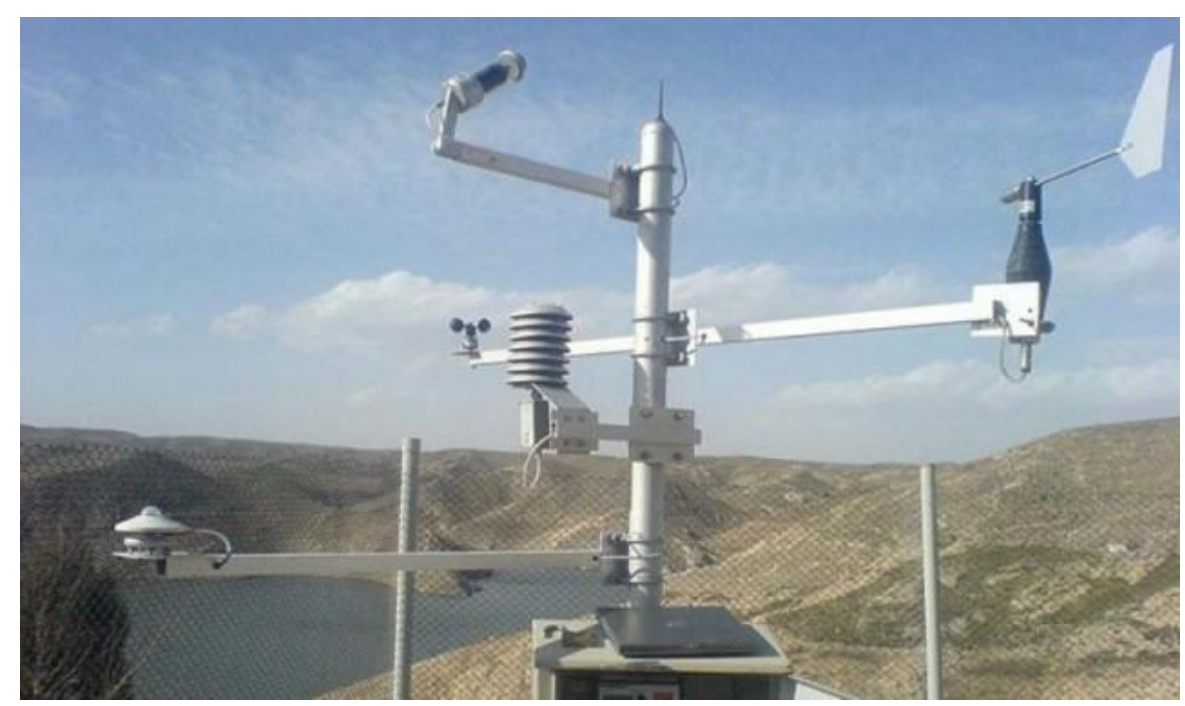

Fig 6. The meteorological station of Bandar Dayyer 
3

\section{Methodology}

Different software programs are used to calculate the wind speed and solar radiation, one of those is the Homer software, which is used by many researchers in the world [34]. In this study, by using Homer software, the wind speed and solar radiation data for Bandar Dayyer are gathered and measured for implementing a hybrid power station in this area. After this step, the simulated results and the amount of electricity production for these systems are investigated. At the end, a comparison investigation between these systems and others is presented in the framework of a table.

\section{The Homer software benefits}

Homer is an optimization and simulation software for renewable energy. This software is able to present a model for the renewable electricity and micro-power optimization for evaluating the designs of both off-grid and grid-connected power systems. In addition, this software can analyze the economy of hybrid renewable energy systems. Indeed, the Homer software models a power system's physical behavior and its life-cycle cost, so that it is able to estimate the total cost of installing and operating of the considered systems. Homer software has three main tasks: simulation, optimization, and sensitivity analysis. For the simulation step, this software models the performance of a specific micro-power system for determining its technical feasibility and life-cycle cost. For the optimization step, Homer is able to analyze and select the feasible system for implementation in the studied areas. For the sensitivity analyses, this software simulates each configuration and discovers the effects which change the factors.

\section{Results and Discussion}

By using the Homer software, technical analysis for this study is performed. Homer software is applied for the techno-economic feasibility of the wind-solar-generator hybrid system. Initially, the related data of wind speed and solar radiation for the studied area were extracted via Iran's weather forecasting website; then, the data were entered to the software and analyzed.

\section{Load demand}

Fig. 7 shows a schematic of the PV-Wind-Diesel-Converter-Battery system. The load demand for this unit is $11.25 \mathrm{kWh} / \mathrm{d}$ and the peak load is estimated at $0.89 \mathrm{~kW}$, which is obvious in Fig. 7. 


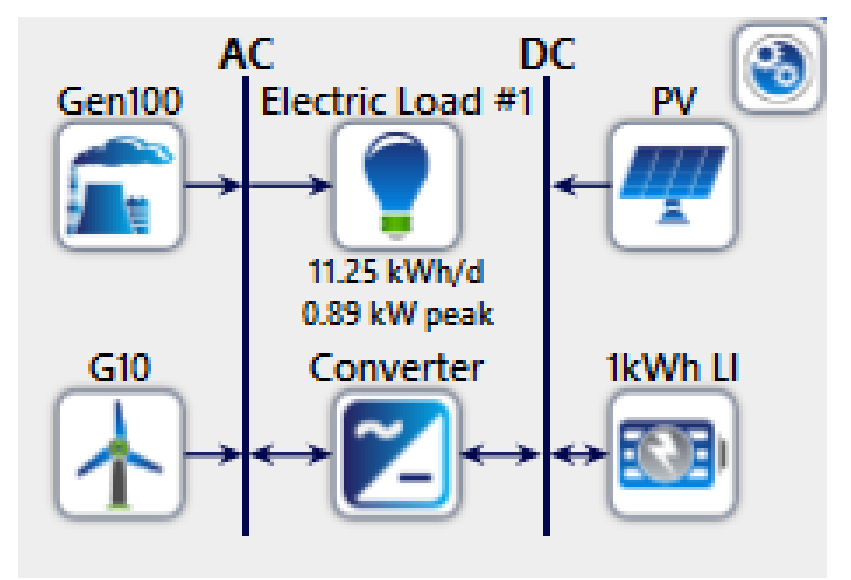

1

4 In this study, two separated units were considered and analyzed for producing electrical energy.

5 In this regard, firstly, the input data were entered to Homer software; then, with regard to the

6 output data, the analyses were carried out.

7

\section{Electrical production analysis}

9 Since producing electrical energy by fossil fuels could lead to environmental issues, the 10

Table 5. Electrical production by each main component for PV-Generic system

\begin{tabular}{ccclcc}
\hline $\begin{array}{c}\text { Generic flat } \\
\text { plate PV }\end{array}$ & Generic 100 & 10 & Production & Fuel \\
consumption $\left(\begin{array}{c}\text { Excess } \\
\text { L) }\end{array}\right.$ & electricity \\
\hline $18862 \mathrm{~kW}$ & 0 & $3545 \mathrm{~kW}$ & $22409 \mathrm{~kW}$ & 0 & $17983 \mathrm{~kW}$ \\
\hline
\end{tabular}


1 To complete this table, Fig. 8 shows the monthly average electric production for the PV-

2 Generic. As it is shown in this figure, among different months, May has the highest amount

3 of electrical production, while December has the lowest amount of electrical production.

4

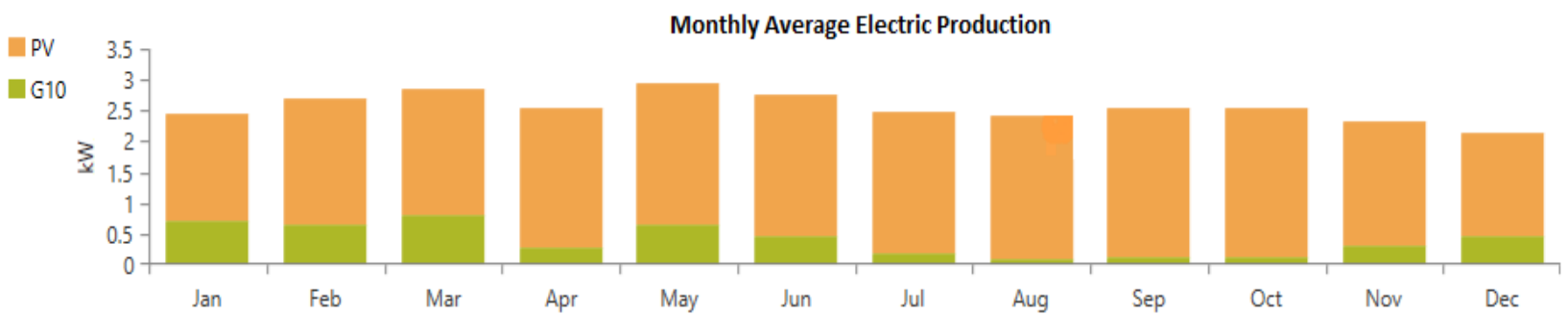

Fig 8. Monthly average electricity production for the PV- Generic system.

In addition, Table 6 shows the electrical production for PV-diesel-Generic system by each main component. With this regard, the total amount of electrical production is $447,767 \mathrm{~kW}$ that most amount electrical production of it is producing by generic $10 \mathrm{~kW}$ and with amount value of $315,481 \mathrm{~kW}$. In addition, this system is able to produce $443,629 \mathrm{~kW}$ excess electricity.

Table 6. The electrical production for PV-diesel-Generic system by each main component.

\begin{tabular}{cccccc}
\hline $\begin{array}{c}\text { Generic flat } \\
\text { plate PV }\end{array}$ & Generic 100 & Generic 10 & Total Production & $\begin{array}{c}\text { Fuel consumption } \\
(\mathrm{L})\end{array}$ & $\begin{array}{c}\text { Excess } \\
\text { electricity }\end{array}$ \\
\hline \multirow{2}{*}{$67536 \mathrm{~kW}$} & $64750 \mathrm{~kW}$ & $\mathrm{~kW}$ & 445481 & & \\
\hline
\end{tabular}

Moreover, Fig. 9 shows the monthly average electrical production by the PV-diesel-Generic. According to the figure, March and August have the highest and lowest amount of electrical production, respectively.

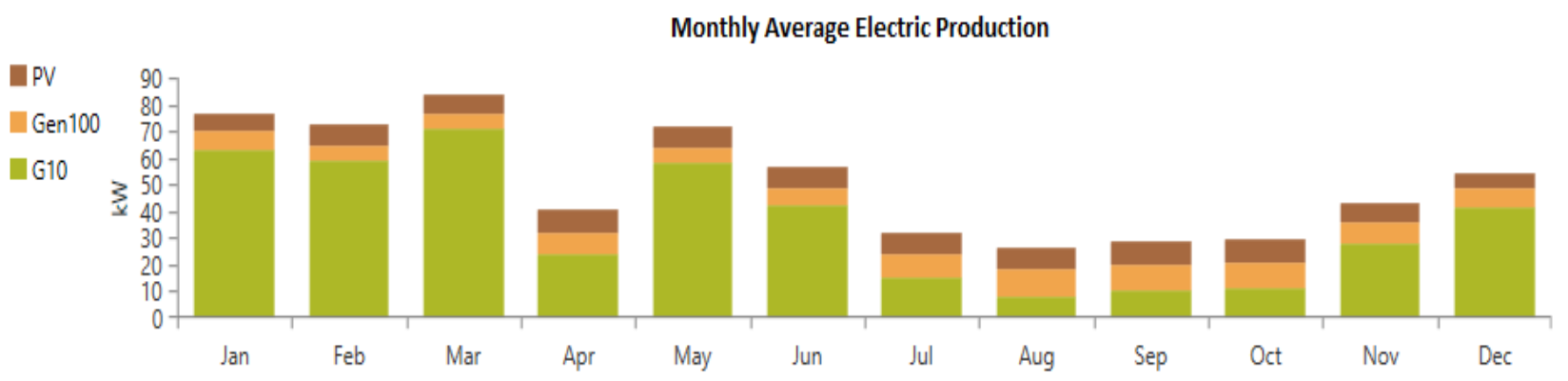

Figs 9. Monthly average electric production by PV-Generator $100 \mathrm{~kW}-$ Generator $10 \mathrm{~kW}$. 


\section{Battery analyses for PV-Wind-Diesel-Converter-Battery system}

2 The importance of battery for energy storage has been caused that selection of this section was

3 done with high accurate by designers of Hybrid systems. Table 7 shows the specifications of 4 the utilized battery for the hybrid unit. As it could be seen, the battery receives $1,744 \mathrm{kWh} / \mathrm{yr}$ 5 and energy out is $1,571 \mathrm{kWh} / \mathrm{yr}$, actually the battery only losses $175 \mathrm{kWh} / \mathrm{yr}$ that it shows the 6 battery has high percent to save energy. Table 7. Specifications of the utilized battery for the hybrid unit

\begin{tabular}{lr}
\hline Energy In $(\mathrm{kWh} / \mathrm{yr})$ & 1744 \\
Energy Out $(\mathrm{kWh} / \mathrm{yr})$ & 1571 \\
Storage Wear Cost $(\$ \mathrm{kWh})$ & 0.0126 \\
Nominal Capacity $(\mathrm{kWh})$ & 25 \\
Lifetime Throughput $(\mathrm{kWh})$ & 24857 \\
Storage Depletion $(\mathrm{kWh})$ & 2 \\
Losses $(\mathrm{kWh})$ & 175 \\
String Size & 1 \\
Bus Voltage $(\mathrm{V})$ & 6 \\
Expected Life (Year) & 15 \\
\hline
\end{tabular}

8 Fig. 10 shows the state of charge for the battery. The oscillating's in this figure demonstrates 9 that this battery does not have $100 \%$ performance, which means in some times the wind turbine 10 and PV are not able to produce and receive energy completely and this system will be forced 11 to use the generator.

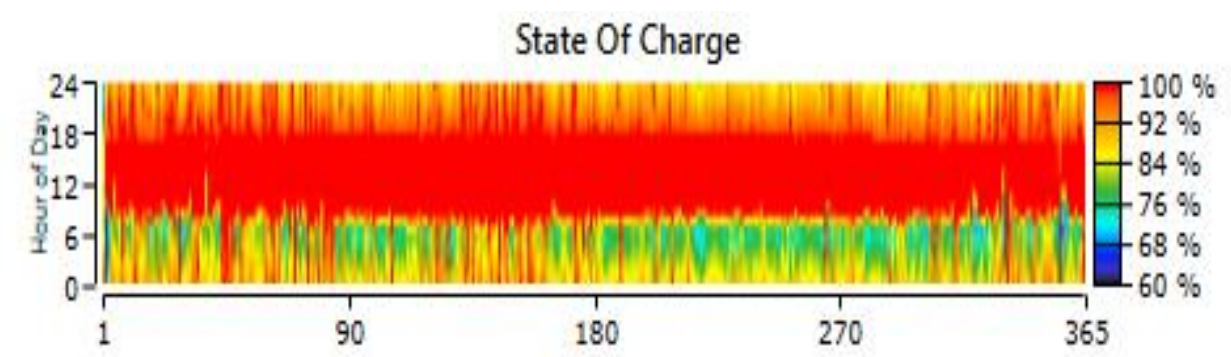




\section{Converter analyses for the hybrid system}

2 The converter is an essential part of each hybrid component. Table 8 demonstrates the total

3 specification of the used converter for the PV-Wind-Converter-Battery System. As it could be

4 seen, this converter has 2,847 amount of energy in and 2,705 amount of energy out with 142

$5 \mathrm{kWh} / \mathrm{yr}$ losses.

Table 8. Specification of the utilized converter

\begin{tabular}{lcc}
\hline Specification & Inverter & Rectifier \\
\hline Hours of Operation (hrs/yr) & 7044 & 327 \\
Energy In (kWh/yr) & 2847 & 126 \\
Energy Out (kWh/yr) & 2705 & 120 \\
Losses (kWh/yr) & 142 & 6.32 \\
Capacity $(\mathrm{kW})$ & 1.17 & 1.17 \\
Mean Output $(\mathrm{kW})$ & 0.309 & 0.0137 \\
\hline
\end{tabular}

7

8

9

10

11

12

\section{Economic evaluation}

Careful and accurate technical-economic evaluation of solar and wind potentials is considered as the most important step in the construction of wind or solar power system because these evaluations are the pre-requirements of a successful source utilization plan. Parameters required for such evaluations can be obtained by the following formulas.

Net present cost can be calculated by the following equation [35]:

$N P C=\frac{\operatorname{Ctann}}{\operatorname{CRF}(i, T p)}$

$N P C$ in the above formula is the net present cost (in dollars), Ctann is the total annualized cost, $C R F$ is the capital recovery factor, $i$ is the real annual interest rate (in percentage) and $T_{p}$ is the period of the project.

Capital recovery factor can be calculated by the following formula:

$C R F(i, n)=\frac{i(1+i)^{n}}{(1+i)^{n}-1}$

In the above formula, $C R F$ is the capital recovery factor, $i$ the nominal interest rate and $n$ is the number of years. In the Homer software, the energy cost balance can be obtained from the following equation [35]: 
$1 \quad C O E=\frac{\text { Ctann }}{\text { Eis+Egrid }}$

2 In the above formula, COE is the levelized cost of energy, Ctann is the total annualized cost;

3 Eis is the electrical energy that the micro grid system actually serves, and Egrid is the amount

4 of electricity sold to the grid by micro grid.

5 Table 9 shows the output economic analyses for two considered systems. As it is shown in the

6 table, the total NPC for the PV-Diesel-Wind-Converter system is approximately more eight

7 times of PV-Wind-Converter-Battery system, and so on the costs of PV-Diesel-Wind-

8 Converter system is more.

Table 9. The output economic analyses for two considered systems

\begin{tabular}{lccccc}
\hline System & Total NPC & $\begin{array}{c}\text { Levelized } \\
\text { COE }\end{array}$ & $\begin{array}{c}\text { Operating } \\
\text { Cost }\end{array}$ & $\begin{array}{c}\text { Present } \\
\text { Worth }\end{array}$ & $\begin{array}{c}\text { Annual } \\
\text { Worth }\end{array}$ \\
\hline $\begin{array}{l}\text { PV-Wind-Converter- } \\
\text { Battery }\end{array}$ & $\$ 23148.84$ & $\$ 0.44$ & $\$ 260.59$ & $\$ 17316$ & $\begin{array}{c}\$ / \mathrm{yr}) \\
\text { PV-Diesel-Wind- }\end{array}$ \\
\begin{tabular}{l} 
Converter \\
\hline
\end{tabular} & $\$ 186969.00$ & $\$ 3.52$ & $\$ 12623.38$ & $\$ 181136$ & $(\$ / \mathrm{yr})$ \\
\hline
\end{tabular}

12 Table 10 demonstrates the cost summary for the PV-Wind- Battery-Converter. The highest cost 13 value in this system belongs to the generic $10 \mathrm{~kW}$ with $\$ 15,000$, and the lowest cost value is 14 for the converter with a value of $\$ 280$. In addition, the total cost value for this system is $15 \$ 23,148.84$.

Table 10. Cost summery for PV-Wind- Battery-Converter System

18

\begin{tabular}{lllllll}
\hline Component & Capital \$ & Replacement \$ & Q\&M $(\$)$ & $(\$)$ & $(\$)$ & Total $(\$)$ \\
\hline Generic 10 kW & 15000 & 3825.69 & 646.38 & 0 & 2156.02 & 17316.04 \\
Generic 1kW Li - & & & & & & \\
Lon & 1000 & 381.85 & 129.28 & 0 & 71.87 & 1439.25 \\
Generic flat plate PV & 3500 & 0 & 387.83 & 0 & 0 & 3887.83 \\
Converter & 280 & 118.8 & 129.28 & 0 & 22.36 & 505.71 \\
System & 19780 & 4326.33 & 1292.75 & 0 & 2250.25 & 23148.84 \\
\hline
\end{tabular}


1 Also, table 11 indicates the cost summary analysis for the PV-Wind-Diesel-Converter. The

2 lowest cost value was estimated for the converter with $\$ 280$, while the highest cost value was

3 for the generic $10 \mathrm{~kW}$ with a value of $\$ 15,000$. In addition, the total cost value for this system

4 was $\$ 186,968.99$.

5

Table 11. Cost summary for the PV-Wind-Diesel-Converter system

\begin{tabular}{lllllll}
\hline & Capital & Replacement & Q\&M & \multicolumn{3}{l}{ Salvage } \\
Component & $(\$)$ & $(\$)$ & $(\$)$ & Fuel $(\$)$ & $(\$)$ & Total $(\$)$ \\
\hline Generic 10 kW & 15000 & 3825.69 & 646.38 & 0 & 2156.02 & 17316.04 \\
Generic 100 kW & 5000 & 7481.70 & 669.65 & 152762.85 & 654.79 & 165259.40 \\
Generic flat plate & & & & & & \\
PV & 3500 & 0 & 387.83 & 0 & 0 & 3887.83 \\
Converter & 280 & 118.8 & 129.28 & 0 & 22.36 & 505.71 \\
System & 23780 & 11426.19 & 1833.12 & 152762.85 & 2833.17 & 186968.99 \\
\hline
\end{tabular}

7

$8 \quad$ Validation

9 A comparison of the results of the present simulation with the published literature with similar electrical power demand is presented here. Since the main goal of the hybrid systems is energy production, thus different types of the hybrid units could be used and coupled for this target.

12 Table 12 shows a comparison of the results of the study with other similar cases. As it is shown,

13 various types of hybrid systems with different amount of energy production are presented in 14 Table 12.

Table 12. A comparison of results of the study with other similar electric power demand situation

\begin{tabular}{llll}
\hline System & $\begin{array}{l}\text { Total electrical } \\
\text { production }\end{array}$ & $\begin{array}{l}\text { High producer section and amount } \\
\text { of electric production }\end{array}$ & Authors \\
\hline PV-Wind- & & Wind turbine & Qolipour et al. [36] \\
Generator & $49835 \mathrm{~kW}$ & $25230 \mathrm{~kW}$ & \\
& & PV & Hiendro et al. [37] \\
PV-Wind & $2575 \mathrm{~kW}$ & $2079 \mathrm{~kW}$ & \\
PV-Wind- & & Wind turbine generic 10 & Present study (case 1) \\
Generator & $447767 \mathrm{~kW}$ & $315481 \mathrm{~kW}$ &
\end{tabular}


Diesel generator $5 \mathrm{~kW}$

\begin{tabular}{|c|c|c|c|}
\hline PV-Generator & $37948 \mathrm{~kW}$ & $\begin{array}{l}25379 \mathrm{~kW} \\
\text { Wind turbine }\end{array}$ & Shaahid et al. [38] \\
\hline Wind-Generator & $2641666 \mathrm{kWh}$ & $\begin{array}{l}1807624 \mathrm{kWh} \\
\text { Wind turbine generic } 10\end{array}$ & Himri et al. [39] \\
\hline PV-Wind & $22409 \mathrm{~kW}$ & $\begin{array}{l}3545 \mathrm{~kW} \\
\mathrm{PV}\end{array}$ & Present study (case 2) \\
\hline $\begin{array}{l}\text { PV-Generator } \\
\text { PV-Wind-Fuel }\end{array}$ & $31722 \mathrm{~kW}$ & $\begin{array}{l}26567 \mathrm{~kW} \\
\text { Wind turbine }\end{array}$ & Ismail et al. [40] \\
\hline $\begin{array}{l}\text { cell } \\
\text { PV-Wind- }\end{array}$ & $2126048 \mathrm{~kW}$ & $\begin{array}{l}1461955 \mathrm{~kW} \\
\text { Generator }\end{array}$ & Kalinci et al. [41] \\
\hline Generator & $229617054 \mathrm{~kW}$ & $156680000 \mathrm{~kW}$ & Ahmad et al. [42] \\
\hline
\end{tabular}

1

2

3 Conclusion

$4 \quad$ Achieving energy sustainability using renewable energy has many advantages such as reducing 5 fossil fuels and reliable energy supply for deprived areas, especially in the developing 6 
2 Nomenclature

\begin{tabular}{ll}
\hline ARDL & Applying the autoregressive distributed lag \\
COE & Levelized cost of energy \\
CRF & Capital recovery factor \\
Ctann & Total annualized cost \\
GDP & Gross Domestic Product \\
Eis & Electrical energy of the micro-grid system \\
Egrid & Amount of electricity sold to the grid by micro-grid \\
i & Real annual interest rate \\
HESS & Hybrid energy storage system \\
HRES & Hybrid renewable energy system \\
n & Number of years \\
NPC & Net present cost \\
PHS & Pumped hydro storage \\
PV & Photovoltaic \\
SEMA & Smart energy management algorithm \\
Tp & Period of the project \\
\hline
\end{tabular}

3

4 References

5 1. Byrne, J., B. Shen, and W. Wallace, The economics of sustainable energy for rural

54.

2. Heidari, A., A. Hajinezhad, and A. Aslani, A Sustainable Power Supply System, Iran's Opportunities via Bioenergy. Environmental Progress \& Sustainable Energy, 2019. 38(1): p. 171-188.

3. Shirmohammadi, R., M. Soltanieh, and L.M. Romeo, Thermoeconomic analysis and optimization of post-combustion $\mathrm{CO} 2$ recovery unit utilizing absorption refrigeration system for a natural-gas-fired power plant. Environmental Progress \& Sustainable Energy, 2018. 37(3): p. 1075-1084.

4. Rahmani, K., et al., Wind power assessment and site matching of wind turbines in Lootak of Zabol. International Journal of Renewable Energy Research (IJRER), 2014. 4(4): p. 965-976.

5. Razmjoo, A. and A. Davarpanah, Developing various hybrid energy systems for residential application as an appropriate and reliable way to achieve Energy sustainability. Energy Sources, Part A: Recovery, Utilization, and Environmental Effects, 2019. 41(10): p. 11801193.

6. Khatibi, A., S. Pourebrahim, and A. Danehkar, A cellular automata model for monitoring and simulating urban land use/cover changes toward sustainability. Journal of Environmental Engineering and Landscape Management, 2018. 26(1): p. 1-7. 
7. Khatibi, A., S. Pourebrahim, and M. Bin Mokhtar, Simulating carbon sequestration using cellular automata and land use assessment for Karaj, Iran. Solid Earth, 2018. 9(3): p. 735744.

8. Razmjoo, A., et al., Design and Built a Research AUV Solar Light Weight. International Journal of Energy and Power Engineering, 2015. 4(5): p. 268-274.

9. Mohammadnezami, M., et al., Meeting the electrical energy needs of a residential building with a wind-photovoltaic hybrid system. Sustainability, 2015. 7(3): p. 2554-2569.

10. Mehrpooya, M., M. Mohammadi, and E. Ahmadi, Techno-economic-environmental study of hybrid power supply system: A case study in Iran. Sustainable Energy Technologies and Assessments, 2018. 25: p. 1-10.

11. Mohammadi, M., et al., Optimal planning of renewable energy resource for a residential house considering economic and reliability criteria. International Journal of Electrical Power \& Energy Systems, 2018. 96: p. 261-273.

12. Rezvani, A., et al., Intelligent hybrid power generation system using new hybrid fuzzy-neural for photovoltaic system and RBFNSM for wind turbine in the grid connected mode. Frontiers in Energy, 2019. 13(1): p. 131-148.

13. Sameti, M., A. Kasaeian, and F.R. Astaraie, Simulation of a ZEB Electrical Balance with aHybrid Small Wind/PV. Science and Education, 2014. 2(1): p. 5-11.

14. Soltani, S., et al., An experimental investigation of a hybrid photovoltaic/thermoelectric system with nanofluid application. Solar Energy, 2017. 155: p. 1033-1043.

15. Jahangiri, M., et al., Assessment of solar-wind power plants in Afghanistan: A review. Renewable and Sustainable Energy Reviews, 2019. 99: p. 169-190.

16. Kasaeian, A., et al., Effects of forced convection on the performance of a photovoltaic thermal system: An experimental study. Experimental Thermal and Fluid Science, 2017. 85: p. 13-21.

17. Sen, R. and S.C. Bhattacharyya, Off-grid electricity generation with renewable energy technologies in India: An application of HOMER. Renewable Energy, 2014. 62: p. 388-398.

18. Ma, T., et al., Technical feasibility study on a standalone hybrid solar-wind system with pumped hydro storage for a remote island in Hong Kong. Renewable energy, 2014. 69: p. 715.

19. Ntanos, S., et al., Renewable energy and economic growth: Evidence from European countries. Sustainability, 2018. 10(8): p. 2626.

20. Amrollahi, M.H. and S.M.T. Bathaee, Techno-economic optimization of hybrid photovoltaic/wind generation together with energy storage system in a stand-alone microgrid subjected to demand response. Applied Energy, 2017. 202: p. 66-77.

21. Ma, T., H. Yang, and L. Lu, Development of hybrid battery-supercapacitor energy storage for remote area renewable energy systems. Applied Energy, 2015. 153: p. 56-62.

22. Aktas, A., et al., Experimental investigation of a new smart energy management algorithm for a hybrid energy storage system in smart grid applications. Electric Power Systems Research, 2017. 144: p. 185-196.

23. Bölük, G. and M. Mert, The renewable energy, growth and environmental Kuznets curve in Turkey: An ARDL approach. Renewable and Sustainable Energy Reviews, 2015. 52: p. 587595.

24. Razmjoo, A., et al., Energy sustainability analyses using feasible indicators for urban areas. International Journal of Energy and Water Resources, 2019: p. 1-14.

25. Goel, S. and R. Sharma, Performance evaluation of stand alone, grid connected and hybrid renewable energy systems for rural application: A comparative review. Renewable and Sustainable Energy Reviews, 2017. 78: p. 1378-1389.

26. Jung, J. and M. Villaran, Optimal planning and design of hybrid renewable energy systems for microgrids. Renewable and Sustainable Energy Reviews, 2017. 75: p. 180-191. 
27. Razmjoo, A., A. Davarpanah, and M.S. Heibati, Implementation analysis of technicaleconomic solar and wind energy potential for small homes: a case study. Environmental Risk Assessment and Remediation, 2017. 1(1): p. 7-12.

28. McCollum, D.L., V. Krey, and K. Riahi, An integrated approach to energy sustainability. Nature Climate Change, 2011. 1(9): p. 428.

29. Razmjoo, A.A. and A. Davarpanah, The Role of Renewable Energy to Achieve Energy Sustainability in Iran. An Economic and Technical Analysis of the Hybrid Power System. Technology and Economics of Smart Grids and Sustainable Energy, 2019. 4(1): p. 7.

30. Armin Razmjoo, A., A. Sumper, and A. Davarpanah, Energy sustainability analysis based on SDGs for developing countries. Energy Sources, Part A: Recovery, Utilization, and Environmental Effects, 2019: p. 1-16.

31. Chu, S. and A. Majumdar, Opportunities and challenges for a sustainable energy future. nature, 2012. 488(7411): p. 294.

32. Singer, S., et al., The energy report. 100\% renewable energy by 2050. 2011.

33. Shirmohammadi, R. and N. Gilani, Effectiveness enhancement and performance evaluation of indirect-direct evaporative cooling system for a wide variety of climates. Environmental Progress and Sustainable Energy, 2018: p. 10.1002/ep.13032.

34. Liu, W.T., W. Tang, and X. Xie, Wind power distribution over the ocean. Geophysical Research Letters, 2008. 35(13).

35. Hafez, O. and K. Bhattacharya, Optimal planning and design of a renewable energy based supply system for microgrids. Renewable Energy, 2012. 45: p. 7-15.

36. Qolipour, M., et al., Evaluation of wind power generation potential using a three hybrid approach for households in Ardebil Province, Iran. Energy Conversion and Management, 2016. 118: p. 295-305.

37. Hiendro, A., et al., Techno-economic analysis of photovoltaic/wind hybrid system for onshore/remote area in Indonesia. Energy, 2013. 59: p. 652-657.

38. Shaahid, S. and M. Elhadidy, Economic analysis of hybrid photovoltaic-diesel-battery power systems for residential loads in hot regions $-A$ step to clean future. Renewable and Sustainable Energy Reviews, 2008. 12(2): p. 488-503.

39. Himri, Y., et al., Techno-economical study of hybrid power system for a remote village in Algeria. Energy, 2008. 33(7): p. 1128-1136.

40. Ismail, M.S., M. Moghavvemi, and T. Mahlia, Techno-economic analysis of an optimized photovoltaic and diesel generator hybrid power system for remote houses in a tropical climate. Energy conversion and management, 2013. 69: p. 163-173.

41. Kalinci, Y., A. Hepbasli, and I. Dincer, Techno-economic analysis of a stand-alone hybrid renewable energy system with hydrogen production and storage options. international journal of hydrogen energy, 2015. 40(24): p. 7652-7664.

42. Ahmad, J., et al., Techno economic analysis of a wind-photovoltaic-biomass hybrid renewable energy system for rural electrification: A case study of Kallar Kahar. Energy, 2018. 148: p. 208-234. 